\title{
LESSON STUDY MELALUI MODEL TWO STAY TWO STRAY BERBANTUAN MIND MAP DALAM PENINGKATAN KUALITAS PEMBELAJARAN KELAS XI MIA 2 MAN TARAKAN
}

\section{Lesson Study through Two Stay Two Stray Model Assisted With Mind Map in Improving The Quality of Learning at Class XI MIA 2 MAN Tarakan}

\author{
Sudarsih $^{\text {a* }}$ Zulfadli $^{\mathrm{b}}$ dan Endik Deni Nugroho ${ }^{\mathrm{b}}$ \\ a Mahasiwa Program Studi Pendidikan Biologi, Universitas Borneo Tarakan, Tarakan, Kalimantan Utara \\ b Program Studi Pendidikan Biologi, Universitas Borneo Tarakan, Tarakan, Kalimantan Utara \\ ${ }^{*}$ Corresponding author: Jl. Amal Lama, Tarakan Timur, Tarakan, Kalimantan Utara, 77123, Indonesia.E-mail: \\ sudarsih.bio@gmail.com
}

\section{Abstrak}

Penelitian ini memiliki 2 tujuan, yaitu: 1) Meningkatkan kompetensi pedagogik guru dengan menerapkan model pembelajaran kooperatif tipe Two Stay Two Stray berbantu mind map melalui Lesson Study; dan 2) Meningkatkan hasil belajar peserta didik dengan menerapkan model pembelajaran kooperatif tipe Two Stay Two Stray berbantu mind map melalui Lesson Study. Jenis penelitian ini adalah Penelitian Tindakan Kelas berbasis Lesson Study. Pengumpulan data dilakukan dengan tes, lembar kuisioner, lembar observasi, dan dokumentasi. Hasil Penelitian menunjukkan bahwa dengan menggunakan model pembelajaran kooperatif tipe two stay two stray berbantu mind map melalui lesson study dapat meningkatkan kompetensi pedagogik guru dan hasil belajar peserta didik.

\section{Kata kunci}

Two Stray Two Stay, Mind Map, Lesson Study

\begin{abstract}
There are 2 aims in this study, i.e.: 1) to increase teacher's pedagogical competencies by applying cooperative learning model Two Stray Two Stay with Mind Map through Lesson Study; and 2) to increase the student's learning results by applying cooperative learning model Two Stray Two Stay with Mind Map through Lesson Study. This study used classroom action research based on Lesson Study. Data collection used test, questionnaire, observing checklist, and documentation. The result of this study showed that Two Stray Two Stay Learning Model with Mind Map through Lesson Study increased teacher's pedagogical competencies and student's learning results
\end{abstract}

Keywords

Two Stray Two Stay, Mind Map, Lesson Study 


\section{Pendahuluan}

Beberapa faktor penting dapat mempengaruhi kualitas pendidikan dalam sebuah jenjang pendidikan. Setiap proses pendidikan di sebuah lembaga pendidikan, guru menempati posisi sentral dan merupakan ujung tombak keberhasilan dalam meningkatkan hasil belajar. Guru merupakan pemegang peran terlibat langsung dalam upaya mempengaruhi, membina dan mengembangkan kemampuan anak didik supaya menjadi manusia yang cerdas, terampil dan bermoral tinggi. Oleh karena itu, guru dituntut untuk memiliki kemampuan yang baik dlam tanggungjawabnya sebagai seorang pendidik dan pengajar. Guru harus menguasai materi pelajaran dan terampil di dalam menyampaikannya serta dapat memilih metode pembelajaran yang sesuai dan tepat dalam proses pembelajaran. (Suryosubroto 1997).

Guru yang inovatif, kreatif, dan produktif adalah guru yang selalu mencari dan menemukan hal-hal baru dan mutakhir untuk kepentingan kualitas pembelajaran dikelas. Upaya untuk meningkatkan pembelajaran di kelas, guru dapat menerapkan model-model pembelajaran yang bervariasi dan tidak hanya menerapkan model pembelajaran yang sama dalam setiap pembelajaran. Selain itu seorang guru juga dituntut untuk mempunyai kompetensi pedagogik. Kompetensi pedagogik adalah kemampuan yang harus dimiliki oleh seorang guru dalam mengelola kegiatan pembelajaran peserta didik yang meliputi pemahaman terhadap peserta didik, perencanaan dan pelaksanaan pembelajaran, serta evaluasi belajar peserta didik (Kunandar, 2010).

Berdasarkan hasil observasi awal dan diskusi dengan guru biologi di MAN Tarakan, diketahui bahwa pencapaian hasil belajar biologi selama ini masih rendah. Hal ini ditunjukkan pada hasil rata-rata nilai klasikal ulangan harian dari 38 peserta didik yang nilainya masih dibawah KKM sebanyak 12 orang dengan persentase nilai klasikal yaitu $31,58 \%$, sedangkan peserta didik yang nilainya sudah mencapai KKM sebanyak 26 orang yaitu dengan persentase sebesar 68,42\%. Berdasarkan uraian tersebut dapat disimpulkan bahwa nilai hasil belajar peserta didik kelas XI MIA 2 MAN Tarakan belum mencapai nilai klasikal. Suatu kelas dikatakan tuntas belajarnya (ketuntasan klasikal) jika dalam kelas tersebut terdapat $\geq 85 \%$ yang telah tuntas belajarnya (Trianto, 2010).

Rendahnya hasil belajar Biologi disebabkan oleh beberapa faktor diantaranya adalah (1) kurangnya persiapan guru dalam pembelajaran, (2) kurangnya kemampuan guru menciptakan pembelajaran yang efektif, variasi, kreatif, dan menyenangkan, (3) sebagian besar peserta didik tidak memperhatikan penjelasan guru di kelas sehingga tujuan pembelajaran tidak tercapai secara maksimal. Menurut Suparlan (2008) pengelolaan pembelajaran menjadi cerminan kualitas pembelajaran, seharusnya guru tidak hanya sekedar mentransfer ilmu tanpa mengembangkan kompetensi yang dimilikinya namun seorang guru juga diharuskan mampu mengendalikan kelas agar pembelajaran yang sedang berlangsung bisa menarik peserta didik untuk belajar.

Seorang guru diharapkan agar menerapkan model pembelajaran yang menarik peserta didik dalam proses pembelajaran di kelas agar suasana di dalam kelas lebih efektif. 


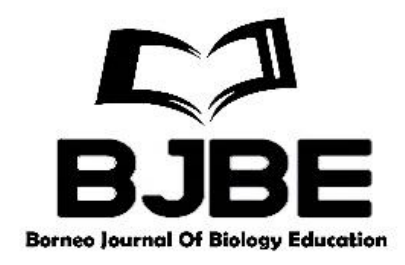

Salah satu model pembelajaran yang diterapkan juga harus sesuai dengan kemampuan dan kebutuhan peserta didik. Adanya variasi dalam model pembelajaran akan mengatasi kejenuhan peserta didik, salah satu model pembelajaran yang digunakan adalah melalui penerapan model pembelajaran kooperatif tipe Two Stay Two Stray (TSTS) berbantu mind map (peta pikiran), karena model pembelajaran ini belum pernah diterapkan di MAN Tarakan, namun berdasarkan penelitian yang dilakukan oleh Sugiarti (2015) model pembelajaran kooperatif tipe TSTS ini dapat meningkatkan hasil belajar.

Solusi untuk mengatasi permasalahan di atas, ialah peneliti menerapkan model pembelajaran yang dapat membantu peserta didik dalam meningkatkan hasil belajar dan melaksanakan lesson study untuk meningkatkan kompetensi pedagogik guru yang meliputi tujuh kompetensi diantaranya meliputi menguasai karakteristik peserta didik, menguasai teori belajar dan prinsip-prinsip pembelajaran yang mendidik, mengembangkan kurikulum, kegiatan pembelajaran yang mendidik, pengembangan potensi peserta didik, komunikasi dengan peserta didik, serta penilaian dan evaluasi. Menurut pendapat Astika (2013), Lesson Studi mendukung terjadinya peningkatan kemampuan profesionalisme guru, khususnya kompetensi pedagogik guru.

Selain itu, pemilihan model pembelajaran yang tepat dapat mempengaruhi kualitas pendidik dalam mengelola pembelajaran. Adapun model pembelajaran yang akan diterapkan dalam penelitian ini adalah model pembelajaran kooperatif tipe Two Stay Two Stray (dua tinggal dua tamu) berbantu mind map (peta pikiran). Diterapkannya model pembelajaran ini diharapkan agar peserta didik tidak hanya belajar dan menerima dari apa yang telah disajikan oleh guru dalam proses belajar mengajar, akan tetapi peserta didik dapat belajar dari peserta didik lainnya sekaligus mempunyai kesempatan untuk mengajarkan kepada peserta didik yang belum paham bahkan kepada kelompok lainnya. Sehingga akan lebih banyak lagi ilmu yang peserta didik informasikan ke peserta didik lainnya. Selain itu, mind map (peta pikiran) juga dapat membantu peserta didik untuk mencatat ide-ide mereka dalam belajar. Buzan (2005) berpendapat bahwa mind map (peta pikiran) adalah cara mencatat yang kreatif, efektif, dan secara harfiah dapat memetakan pikiran-pikiran kita. Penggunaan mind map (peta pikiran) ini sebagai alat untuk membantu peserta didik dalam mencatat ide-ide kreatif mereka dan dapat mendorong peserta didik untuk berpikir sesuai dengan alur berpikirnya, hal tersebut dapat merangsang kretifitas peserta didik dalam belajar dan membentuk karakter peserta didik. Adapun manfaat dari mind map (peta pikiran) ini dapat melatih daya ingat dan kreativitas yang dimiliki sehingga dapat meningkatkan kemampuan dalam menciptakan sesuatu ataupun melakukan sesuatu.

Selanjutnya peneliti juga melaksanakan kajian pengembangan profesionalisme guru melalui Lesson Study. Lesson study adalah suatu proses kolaboratif pada sekelompok guru ketika mengidentifikasi masalah pembelajaran, merancang skenario, membelajarkan peserta didik sesuai skenario, mengevaluasi dan merevisi skenario pembelajaran, membelajarkan kembali skenario pembelajaran yang telah direvisi, mengevaluasi kembali pembelajaran dan membagikan hasilnya dengan guru-guru lain (Herawati Susilo, dkk 


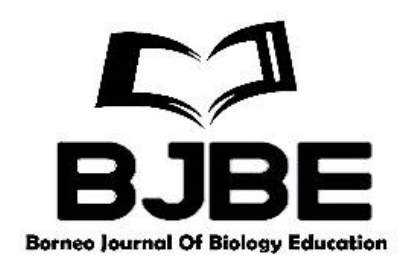

2009; Abrori et al., 2019). Model pembelajaran kooperatif tipe Two Stay Two Stray berbantu mind map (peta pikiran) melalui Lesson Study diharapkan mampu meningkatkan kompetensi pedagogik guru dan hasil belajar peserta didik kelas XI MIA 2 di MAN Tarakan. Dilaksanakannya Lesson Study diharapkan dapat memperbaiki kualitas pembelajaran dari pertemuan ke pertemuan berikutnya pada masing-masing siklus pembelajaran. Perbaikan yang selalu dilakukan diharapkan dapat meningkatkan kualitas pembelajaran guru.

\section{Jenis Penelitian}

\section{Material dan metode}

Jenis penelitian yang digunakan adalah penelitian tindakan kelas (PTK) berkolaborasi dengan Lesson Study mengunakan model pembelajaran Two Stay Two Stray berbantu Mind Map untuk mengetahui peningkatan kompetensi pedagogik guru dan hasil belajar peserta didik kelas XI MIA 2 MAN Tarakan. Pada penelitian ini terdapat tiga tahapan dalam LS yaitu: (1) perencanaan (plan), (2) pelaksanaan (do), (3) refleksi (see). Ketiga tahapan tersebut dilakukan (plan), (2) pelaksanaan (do), (3) refleksi (see). Ketiga tahapan tersebut dilakukan secara terus menerus dan berulang-ulang pada setiap pertemuan.

\section{Subjek, Waktu dan Tempat Penelitian}

Subjek penelitian ini adalah peserta didik kelas XI MIA 2 MAN Tarakan tahun pembelajaran 2016/2017 yang berjumlah 38 orang peserta didik. Penelitian ini dilaksanakan pada tahun pembelajaran 2016/2017 semester genap bertempat di kelas XI MIA 2 MAN Tarakan.

\section{Prosedur Penelitian}

Penelitian ini akan direncanakan dalam tiga siklus. Siklus penelitian tindakan kelas yang digunakan adalah siklus PTK model Kemmis et al., (2013) yang terdiri dari perencanaan, pelaksanaan, observasi, dan refleksi yang dikolaborasikan dengan lesson study yang terdiri dari tiga tahapan yaitu plan, do, dan see. Sebelum siklus I dilaksanakan, peneliti terlebih dahulu melakukan observasi awal.

\section{Instrumen Penelitian, Teknik Pengumpulan dan Analisis Data}

Instrumen penelitian adalah alat ukur yang digunakan untuk menilai proses belajar mengajar yang telah dilaksanakan. Instrumen yang digunakan dalam penelitian ini antara lain: (1) Lembar Observasi yang terdiri dari lembar keterlaksanaan lesson study dan penilaian kompetensi pedagogik guru, (2) Tes hasil belajar peserta didik. Teknik pengumpulan data adalah dokumentasi, tes hasil belajar, dan lembar penilaian kompetensi pedagogik guru. Teknik analisis data dalam penelitian ini menggunakan statistik dengan menghitung nilai hasil belajar secara individual dengan menggunakan rumus:

$$
\text { Nilai }=\frac{\text { Skor yang diperoleh }}{\text { Skor maksimal }} \times 100
$$

Selanjutnya untuk menghitung hasil belajar secara klasikal menggunakan rumus: 


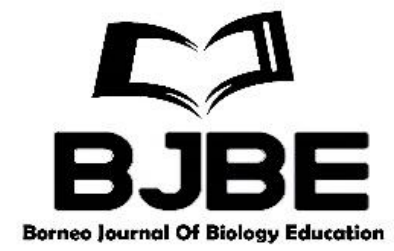

$$
\mathrm{P}=\frac{\sum \mathrm{ni}}{\mathrm{N}} \times 100 \%
$$

Keterangan:

$\mathrm{P} \quad$ : Nilai ketuntasan belajar

$\sum n \mathrm{i} \quad$ : Jumlah siswa tuntas Belajar

$\mathrm{n} \quad$ : Jumlah totas siswa

Kemudian untuk menghitung menghitung angket penilaian kompetensi pedagogik guru dengan menggunakan rumus :

$$
\text { Nilai akhir }=\frac{\text { skor yang diperoleh }}{\text { skor maksimal }} \times 100 \%
$$

\section{Hasil dan Diskusi}

\section{Hasil Rekapitulasi Penilaian Kompetensi Pedagogik Guru}

Penilaian terkait kompetensi pedagogik guru diperlukan untuk mengetahui gambaran keterampilan guru dalam kelas, khususnya yang terkait dengan kompetensi pedagogik, seperti interaksi guru dengan peserta didik, dan cara guru melakukan kegiatan pembelajaran. Hasil penilaian kompetensi ini digambarkan pada Tabel 1.

\begin{tabular}{|c|c|c|c|c|}
\hline No & Aspek Kompetensi & Siklus I (\%) & Siklus II (\%) & Siklus III (\%) \\
\hline 1 & Menguasai karakteristik peserta didik & 65 & 76 & 89 \\
\hline 2 & $\begin{array}{l}\text { Menguasai teori belajar dan prinsip- } \\
\text { prinsip pembelajaran yang mendidik }\end{array}$ & 69 & 75 & 81 \\
\hline 3 & Mengembangkan kurikulum & 64 & 70 & 81 \\
\hline 4 & Kegiatan pembelajaran yang mendidik & 66 & 72 & 76 \\
\hline 5 & Pengembangan potensi peserta didik & 66 & 71 & 82 \\
\hline 6 & Komunikasi dengan peserta didik & 64 & 74 & 81 \\
\hline 7 & Penilaian dan evaluasi & 64 & 73 & 79 \\
\hline & Rata-Rata & 65 & 73 & 81 \\
\hline & Kategori & $\mathrm{C}$ & B & A \\
\hline
\end{tabular}

Tabel 1. Hasil Penilaian Kompetensi Pedagogik Guru

Berdasarkan Tabel 1 diperoleh data melalui lembar penilaian kompetensi pedagogik guru pada siklus I memperoleh nilai rata-rata sebesar $65 \%$ dengan kategori cukup. Kemudian pada siklus II mengalami peningkatan nilai rata-rata sebesar $73 \%$ dengan kategori baik. Sedangkan pada siklus III terjadi peningkatan nilai rata-rata menjadi $81 \%$ dengan kategori sangat baik.

Berdasarkan hasil analisis angket penilaian kompetensi pedagogik guru yang telah dilakukan, dapat diketahui bahwa pada siklus I menunjukkan hasil nilai rata-rata kompetensi pedagogik guru mencapai $65 \%$ dengan kategori cukup. Adapun hal yang 


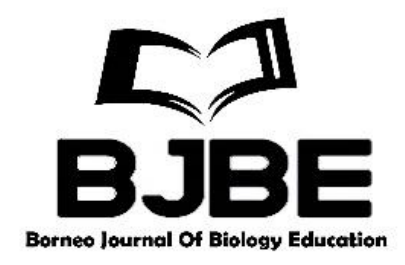

menyebabkan rendahnya kompetensi pedagogik guru pada siklus I ini disebabkan karena peneliti masih belum mampu melaksanakan kegiatan pendahuluan dan penutup dengan baik. Hal ini disebabkan karena peneliti belum bisa mengelola waktu secara efesien. Peneliti terlihat gugup ketika menyampaikan materi pembelajaran sehingga tidak memperhatikan langkah-langkah pembelajaran yang sesuai dengan RPP. Selain itu, peneliti juga belum terbiasa menggunakan model pembelajaran kooperatif tipe Two Stay Two Stray berbantu mind map sehingga pelaksanaan pembelajaran kurang berjalan lancar. Hasil ini membuktikan bahwa kemampuan guru dalam melaksanakan pembelajaran masih belum maksimal.

Berbagai kekurangan pada siklus I telah diperbaiki peneliti dengan memperhatikan kritik, saran, dan masukan dari rekan tim lesson study. Pada tahap see, terjadilah dialog positif yang sangat membantu peneliti dalam memperbaiki kualitas pembelajarannya. Setelah dilakukan perbaikan pada tahap see, hal ini terbukti pada siklus II kompetensi pedagogik guru mengalami meningkan menjadi $73 \%$ dengan kategori baik. Hal ini disebabkan karena dilakukannya perbaikan peneliti telah memperbaiki kekurangankekurangan pada pertemuan sebelumnya. Pada siklus II ini peneliti sudah terlihat lebih santai dalam menyampaikan materi dan mulai terbiasa dalam menerapkan model pembelajaran tersebut. Namun berdasarkan hasil pengamatan yang dilakukan oleh tim observer, masih terdapat beberapa permasalahan peneliti pada saat melaksanakan pembelajaran. Adapun permasalahan tersebut diantaranya adalah peneliti belum bisa mengontrol peserta didik sehingga menyebabkan peserta didik bermain-main, mengobrol, dan saling mengganggu teman kelompoknya masing-masing. Selain itu peneliti juga cenderung mendominan peserta didik tertentu untuk melaksanakan kegiatan persentasi sehingga peserta didik lainnya tidak mendapat kesempatan untuk mempresentasikan hasil diskusi mereka. Hal-hal tersebut menimbulkan peserta didik tidak mendapat kesempatan belajar yang sama dengan peserta didik lainnya. Kemudian kekurangan-kekurangan tersebut direfleksikan pada setiap pertemuan bersama tim observer dan mendapat kritik dan masukan untuk memperbaiki pada pertemuan selanjutnya.

Pernyataan di atas juga sesuai dengan teori yang dikemukakan oleh Syaiful (2009) yaitu kompetensi pedagogik merupakan salah satu jenis yang mutlak yang harus dimiliki oleh setiap guru. Guru yang mempunyai kompetensi pedagogik akan mampu menciptakan lingkungan belajar efektif, menyenangkan dan akan lebih mampu mengelola kelas. Selanjutnya setelah dilakukan perbaikan-perbaikan secara terus menerus pada tahap see yang dilaksanakan pada setiap akhir pertemuan bersama tim lesson study, peneliti dapat melaksanakan pembelajaran dari setiap pertemuan dengan baik. Hal ini dapat dibuktikan bahwa kompetensi pedagogik guru mengalami peningkatan menjadi $81 \%$ dengan kategori baik sekali. Peningkatan tersebut telah mencapai indikator ketercapaian maksimal yang ditargetkan oleh peneliti yaitu 80-100 (\%) dengan kategori sangat baik. Pada siklus III ini peneliti sudah tampak memperbaiki kukuragan-kekurangan pada siklus sebelumnya yaitu peneliti sudah mampu mengontrol peserta didik yang menimbulkan kegaduhan di dalam 


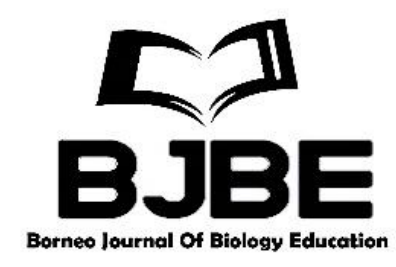

kelas, selain itu peneliti juga lebih menguasai materi pembelajaran dengan baik sehingga menyebabkan peserta didik bisa memahami apa yang disampaikan oleh peneliti.

Peningkatan kompetensi pedagogik dari setiap siklus tidak terlepas dari peran tim lesson study yang telah memberikan kritik, saran dan masukan kepada peneliti. Keberadaan rekan tim lesson study dapat memberikan dampak positif terhadap pelaksanaan pembelajaran di kelas dan mampu mengendalikan aktivitas peneliti yang keluar dari perencanaan pembelajaran. Seorang pendidik dalam hal ini seolah bercermin melalui pengamatan observer. Selain itu, peneliti bisa melihat kelemahan dirinya dan mencari solusi secara bersama untuk memperbaikinya (Suprapti, 2014).

Berdasarkan hasil penelitian tersebut dapat disimpulkan bahwa adanya kolaborasi Lesson Study dapat meningkatkan kompetensi pedagogik guru. Menurut Susilo et al. (2011) Lesson Study bertujuan untuk melakukan pembinaan profesi pendidik secara berkelanjutan, sehingga peningkatan keprofesionalan pendidik dkhususnya pada kompetensi pedagogik guru dapat meningkat secara terus menerus. Upaya tersebut dapat dilakukan dengan pengkajian pembelajaran secara terus menerus dan secara kolaboratif. Pengkajian ini harus dilakukan secara berkala, karena membangun komunitas belajar merupakan membangun budaya. Membangun budaya tidak dapat dilakukan dalam waktu singkat, tetapi membutuhkan waktu lama dimana tidak ada batasan waktu semakin lama semakin baik.

\section{Hasil Rekapitulasi Hasil Belajar Peserta Didik}

Penilaian hasil belajar peserta didik dilakukan untuk mengetahui gambaran secara keseluruhan hasil belajar yang meliputi nilai rata-rata, terendah, tertiingi dan ketuntasan siswa. Hasil rekapitulasi hasil belajar peserta didik disajikan pada Tabel 2.

Tabel 2. Rekapitulasi_Hasil Belajar Peserta Didik

\begin{tabular}{|c|c|c|c|c|}
\hline No & Jenis Data & $\begin{array}{l}\text { Hasil tes } \\
\text { Siklus I }\end{array}$ & $\begin{array}{l}\text { Hasil tes } \\
\text { Siklus II }\end{array}$ & $\begin{array}{c}\text { Hasil tes } \\
\text { Siklus III }\end{array}$ \\
\hline 1 & Nilai terendah & 52 & 56 & 60 \\
\hline 2 & Nilai tertinggi & 88 & 84 & 88 \\
\hline 3 & Nilai rata-rata & 73,94 & 74 & 74,42 \\
\hline 4 & Jumlah siswa yang tidak tuntas belajar & 9 & 7 & 5 \\
\hline 5 & Jumlah siswa yang tuntas belajar & 29 & 31 & 33 \\
\hline 6 & Presentasi yang tidak tuntas & $23.69 \%$ & $18,43 \%$ & $13,15 \%$ \\
\hline 7 & Presentasi yang tuntas & $76,31 \%$ & $81,57 \%$ & $86,85 \%$ \\
\hline
\end{tabular}

Berdasarkan tabel 2 dapat dilihat bahwa nilai yang diperoleh peserta didik sudah dapat dikategorikan baik, walaupun dalam hasil tes di siklus I, siklus II, dan di siklus III masih ada beberapa peserta didik yang nilainya masih belum mencapai Kriteria Ketuntasan Minimal (KKM). Nilai rata-rata peserta didik pada tes di siklus III mengalami peningkatan daripada di siklus II, dan di siklus I dengan rata-rata di tes siklus I sebesar 73,94 naik menjadi 74 di siklus II dan mengalami peningkatan sebesar 74,42 di siklus III. Nilai tertinggi peserta didik mengalami penurunan dan kenaikan meskipun masih diatas standar KKM, dimana nilai tertinggi peserta didik pada siklus I adalah 88 sedangkan pada siklus II menurun menjadi 84 kemudian pada siklus III mengalami kenaikan menjadi 88 


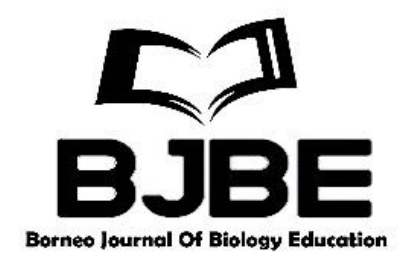

seperti pada siklus I, hal ini bias saja terjadi karena peserta didik kurang memahami materi yang sudah diberikan sehingga belajarnya tidak terlalu bersungguh-sungguh.

Namun untuk peningkatan jumlah peserta didik yang tuntas dari siklus I, siklus II, dan siklus III menunjukkan bahwa peserta didik mulai bisa memahami langkah-langkah pembelajaran yang digunakan yaitu dengan model Two Stay Two Stray berbantu mind map yang diberikan oleh peneliti. Hasil nilai terendah juga mengalami penurunan dari siklus II dan siklus III, dimana nilai terendah pada siklus I adalah 52, siklus II 56, dan siklus III adalah 60. Hal ini dapat disebabkan karena beberapa peserta didik masih belum bisa memahami materi sehingga masih ada yang mendapatkan nilai di bawah standar ketuntasan.

Tabel 2 juga menunjukkan bahwa persentase peserta didik yang tidak tuntas pada siklus I yaitu $23,67 \%$, pada siklus II terjadi penurunan menjadi 18,43\% peserta didik yang tidak tuntas, sedangkan pada siklus III juga mengalami penurunan menjadi $13 \%$ peserta didik yang tidak tuntas. Dilihat dari presentase peserta didik yang tuntas belajarnya yaitu pada siklus I mencapai $76,31 \%$, pada siklus II men6ingkat menjadi $81,57 \%$, selanjutnya pada siklus III juga meningkat menjadi $86,85 \%$.

Berdasarkan hasil penelitian yang dilakukan, bahwa dengan menerapkan model pembelajaran kooperatif tipe Two Stay Two Stray berbantu mind map ini membawa dampak positif terhadap hasil belajar peserta didik. Hal ini ditunjukkan pada persentase ketuntasan hasil belajar peserta didik dari siklus I sampai siklus III meningkat. Pada siklus I persentase ketuntasan hasil belajar peserta didik yaitu mencapai 76,31\%. Ketuntasan hasil belajar tersebut belum mencapai indikator keberhasilan yang ditargetkan oleh peneliti yaitu $85 \%$ sehingga dilanjutkan pada siklus ke II. Kemudian persentase ketuntasan hasil belajar peserta didik pada siklus II meningkat menjadi 81,57\% dan belum menunjukkan ketercapaian indikator yang ditetapkan oleh peneliti yaitu $85 \%$ sehingga dilanjutkan ke siklus III. Selajutnya pada siklus ke III telah menglami peningkatan persentase ketuntasan hasil belajar peserta didik yaitu menjadi $86,85 \%$ dan sudah mencapai indikator keberhasilan yang ditargetkan. Pernyataan di atas didukung oleh Suprihatiningrum (2013) menyatakan bahwa model pembelajaran kooperatif tipe Two Stay Two Stray berbantu mind map melalui lesson study dapat meningkatkan hasil belajar peserta didik. Pembelajaran kooperatif merupakan pembelajaran yang melibatkan peserta didik dalam kelompok yang terdiri dari empat peserta didik dengan kemampuan yang berbeda-beda.

Peningkatan hasil belajar secara klasikal dari siklus I sampai siklus III dapat tercapai karena dipengaruhi hal-hal berikut antara lain: 1) Peserta didik terlibat aktif dalam pembelajaran, 2) Peserta didik lebih cepat memahami materi dengan menggunakan mind map, 3) Peserta didik juga lebih memahami materi pelajaran dengan menerapkan model pembelajaran Two Stay Two Stray, 4) Pada setiap akhir kegiatan pembelajaran guru melakukan evaluasi, 5) Guru juga menjadikan masukan dan saran observer maupun hasil belajar peserta didik sebagai bahan evaluasi perbaikan pembelajaran selanjutnya.

Peningkatan hasil belajar peserta didik dengan menggunakan model pembelajaran kooperatif tipe two stay two stray ini didukung oleh penelitian yang dilakukan oleh Sugiarti (2015) yang dapat meningkatkan hasil belajar peserta didik kelas XI MIA 1 SMA Negeri 1 Prambanan Sleman karena hasil belajarnya telah mencapai KKM pada siklus I yaitu $11,11 \%$ sedangkan pada siklus II meningkat menjadi 77,78\%. Kemudian penelitian lain yang mendukung dalam menggunakan alat bantu berupa mind map yaitu dilakukan oleh Sarasati (2015) dapat meningkatkat hasil belajar peserta didik. 


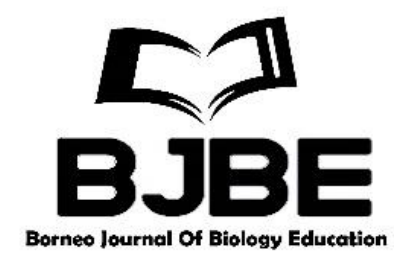

Berdasarkan hasil penelitian dan pembahasan di atas dapat disimpulkan bahwa peningkatan hasil belajar peserta didik tidak terlepas dari kegiatan Lesson Study yang dilaksanakan terus menerus oleh peneliti karena dengan Lesson Study menjadikan peneliti melakukan perbaikan pada pembelajaran berdasarkan refleksi dari pembelajaran sebelumnya. Kekurangan dari perangkat pembelajaran, alat, bahan, media pembelajaran, dan instrumen penilaian, serta teknik pembelajaran oleh peneliti selalu diperbaiki pada pelaksanaan do dari Lesson Study pada pertemuan-pertemuan berikutnya, sehingga dapat memperbaiki kualitas pembelajaran yang pada akhirnya meningkatkan hasil belajar peserta didik. Pernyataan diatas juga didukung teori yang dikemukakan oleh Garfield (2006) menyatakan bahwa Lesson Study adalah proses sistematis yang digunakan guruguru Jepang untuk menguji keefektifan pengajaran dalam rangka meningkatkan pembelajaran. Penelitian ini juga didukung oleh penelitian yang dilakukan oleh Prayitno \& Hidayati (2015) yang menyatakan bahwa adanya peningkatan terjadi karena adanya kegiatan Lesson Study yang dilakukan melalui tahap plan, do, dan see secara terus menerus pada setiap pertemuan.

\section{Kesimpulan}

Bedasarkan paparan data, temuan penelitian, dan pembahasan maka dapat di ambil kesimpulan bahwa penerapan model pembelajaran Two Stay Two Stray berbantu mind map melalui Lesson Study dapat meningkatkan kompetensi pedagogik hal ini dapat dilihat dari meningkatnya kompetensi pedagogik kompetensi dari siklus I hingga ke siklus III yaitu pada siklus I adalah $65 \%$ dengan kategori cukup, siklus II mengalami peningkatan menjadi $73 \%$ dengan kategori baik, sedangkan pada siklus III juga mengalami peningkatan menjadi $81 \%$ dengan kategori sangat baik sehingga dapat dikatakan penelitian ini berhasil mencapai indikator keberhasilan makimal penelitian yaitu sebesar 80-100 (\%) dengan kategori sangat baik. Penerapan model pembelajaran Two Stay Two Stray berbantu mind map melalui Lesson Study dapat meningkatkan hasil belajar peserta didik terlihat dari meningkatnya persentase hasil belajar secara klasikal sebesar $76,31 \%$ pada siklus I, kemudian meningkat pada siklus II sebesar $81,57 \%$ hingga pada siklus III juga meningkat menjadi 86,85\%.

Adapun saran yang ingin disampaikan berkaitan dengan hasil penelitian ini yaitu: guru dapat menerapkan model pembelajaran kooperatif tipe Two Stay Two Stray berbantu Mind Map melalui Lesson Study pada pokok bahasan atau materi yang lain serta pada kelas yang lain untuk meningkatkan kompetensi pedagogik guru dan hasil belajar peserta didik. Selain itu, penerapan model pembelajaran kooperatif tipe Two Stay Two Stray berbantu Mind Map melalui Lesson Study, guru dapat memberikan mind map tersebut sebagai tugas individu terlebih dahulu sebagai acuan untuk pembuatan mind map secara kelompok

\section{Daftar Pustaka}

Abrori, F. M., Krisnawati, Y., Ningsih, R., \& Usman, U. (2019). Penelitian tindakan kelas berbasis lesson study: model think pairshare berbantuan media komik protista untuk 


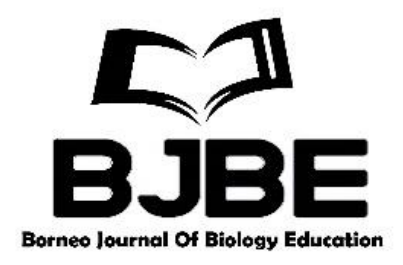

meningkatkan hasilbelajar biologi. Borneo Journal of Biology Education, 1(1), 17.

Arikunto, S. (2013). Prosedur Penelitian Suatu Pendekatan Praktik. Jakarta: Rineka Cipta.

Arikunto, S., \& Suhardjono, S. (2015). Penelitian Tindakan Kelas Edisi Revisi. Jakarta: Bumi Aksara.

Aris, S.. (2014). 68 Model Pembelajaran Inovatif dalamKurikulum 2013. Yogyakarta : Ar-Ruzz Media.

Aunnurahman. (2012). Belajar dan Pembelajaran. Bandung :Alfabeta.

Buzan, T. (2010). Buku Pintar Mind Mapping. Jakarta: PT Gramedia.

Daryanto \& Muljo, R. (2012). Model Pembelajaran Inovatif. Yogyakarta: Gava Media.

Garfield, J. (2006). Exploring the Impact of Lesson Study on Developing Effective Statistics Curriculum. University of Minnesota

Kemmis, S., McTaggart, R., \& Nixon, R. (2013). The action research planner: Doing critical participatory action research. Springer Science \& Business Media.

Kunandar. (2010). Guru Profesional. Jakarta: Rajawali Press.

Mulyasa, E. (2011). Standar Kompetensi dan Sertifikasi Guru. Bandung: Remaja Rosda Karya.

Prayitno, T. A., \& Hidayati, N. (2016). Penerapan Lesson Study pada Kegiatan Praktikum Mikrobiologi Program Studi Pendidikan Biologi IKIP Budi Utomo Malang. Bioedukasi UNS, 9(1), 51-56.

Rusman. (2013). Model-Model Pembelajaran. Jakarta: Raja Grafindo Persada.

Susilo, H., Husnul, C., Ridwan, J., \& Jumiati, Y. (2009). Lesson study berbasis sekolah: Guru konservatif menuju guru inovatif. Malang: Bayumedia.

Sarasati, S. (2015) . Upaya Peningkatan Motivasi dan Hasil Belajar Biologi Siswa Menggunakan Metode Mind Map Kelas X A MAN Lab UIN Yogyakarta Tahun Ajaran 2014/2015. Skripsi. UIN Sunan Kalijaga. Yogyakarta.

Sugiarti, N. (2015) Penerapan Metode Pembelajaran Two Stay Two Stray (TSTS) Pada Materi Sistem Imun Dalam Meningkatkan Minat dan Hasil Belajar Siswa Kelas Xi Mia 1 Sma Negeri 1 Prambanan Sleman, Yogyakarta. Skripsi. Universitas Sanata Dharma. Yogyakarta

Suparlan. (2008). Menjadi Guru Efektif. Jakarta: Hikaya Publishing.

Suprapti. (2014). Pengalaman Berharga dari Lesson Study bagi Guru-guru IPA di Kabupaten Subang. Proceding Become Reflective Educators and Professionals of Learning. Bandung: WALS International Conference.

Suprihatiningrum, Jamil. (2013). Strategi Pembelajaran teori \& aplikasi. Yogyakarta:ArRuzz Media

Syaiful, S. (2009). Kemampuan Profesional Guru dan Tenaga Kependidikan, Bandung: Alfabeta 
BJIEE 